\title{
Infrastructure Investment and the Emerging Role of Institutional Investors: The Case of Pension Funds and Sovereign Wealth Funds
}

\author{
Joseph B. Oyedele \\ Department of Estate Management, Obafemi Awolowo University, \\ Ile-Ife, Osun State, Nigeria \\ Email:joe_christ2001@yahoo.co.uk
}

\section{Doi:10.5901/ajis.2014.v3n1p43}

\begin{abstract}
The search for innovative means of financing infrastructure has become incessant as the demand pressure and the plethora of evidences observed in the form of increasing infrastructure financing gap, ageing infrastructure, environmental factors, such as climate change, rising quality standards are factors attracting institutional and private sector participation in infrastructure investment. Also, the features of the financial landscape, especially in a financial crisis has further underpinned the significance of looking beyond the present infrastructure need, to a more sustained infrastructure financing scheme anticipated from institutional investors. This paper therefore conceptually investigates the potentials of pension funds and sovereign wealth funds (SWF) in bridging the global infrastructure funding gap. A fundamental findings from the study revealed that institutional investors particularly pension funds and sovereign funds have the capacity to pool enormous resources into the infrastructure market, thus emphatically projecting them as a force to be reckoned with in the global infrastructure investments.
\end{abstract}

Keywords: Infrastructure, Investment, Pension Funds and Sovereign Wealth Funds

\section{Introduction}

Infrastructure has acquired increased investment significance with capital flows from institutional investors seeking exposure to alternative assets for enhanced performance and diversification benefits. Previously, the asset allocation for infrastructure by many institutional investors and superannuation funds was seen as part of their property allocation. However, there has been significant growth and maturity in the infrastructure sector; such that it is now considered to be a property-related, but separate asset class. As a result, many institutional investors and superannuation funds now have a unique and separate asset allocation to infrastructure and the infrastructure sub-sectors (Peng and Newell, 2007).

Also, the search for innovative vehicles in financing infrastructure has become incessant as the demand pressure and the plethora of evidences observed in the form of increasing infrastructure gap financing, ageing infrastructure, environmental factors, such as climate change, rising quality standards are factors attracting institutional and private sector participation in infrastructure investment. Other infrastructure financing lacuna includes government fiscal budgetary constraints and historical underinvestment in crucial infrastructure projects. These are drivers compelling the emergence of key institutional players such as pension funds, private equity funds, hedge funds, mutual funds and the most recent and ubiquitous sovereign wealth funds

Merna and Njiru (2002) point out that this financing gap and the growing realization of the limitations of public funding for infrastructure development has been an issue since the 1980s. These constraints tend to render the conventional means of financing infrastructure inadequate as most governments from both developed and developing countries are confronted with the challenge of meeting up with or increasing infrastructure needs and the obvious financing gap, clearly indicating the need for a more cognizant development of adequate financing structures for the provision of infrastructure. Accordingly, recognition of this funding gap has consequently attracted a universal acceptance of a larger role of institutional investors in the financing of infrastructure.

Economic growth tends to be central to the search for an alternative mode of financing infrastructure and the huge fiscal deficit of government budgets across the globe will provide an opportunity to rethink partnerships. With the drive towards the privatization of most government public assets, Kim (1997) highlights that the capacity of a sector is judged by its ability to adequately provide finance since the efficiency of the financing vehicle determines to a large extent the performance and the scope of expansion for a given project. As a result, adequate financing mechanisms for urban infrastructure, its operation and maintenance is a precondition in ensuring that cities function effectively and efficiently too 
as the engines of growth.

The choice of infrastructure financing mechanism and the optimal investment strategies for potential returns tend to be influenced by the inclination to offer paramount value for money and the nature of risk associated with a given infrastructure investment mechanism. In addition, the nature of the financial landscape, especially in a financial crisis has further reinforced and necessitated the significance of looking beyond the present infrastructure need, to a more sustained infrastructure financing blueprint and more innovative financing vehicles.

This paper therefore investigates the potentials of pension funds and sovereign funds in bridging the global infrastructure funding gap. The rest of the paper presents definition and classification of Infrastructure in section two; significance and economic competitive attraction of infrastructure in section three; institutional investment characteristics in section four; pension funds in section five; sovereign funds in section six and the conclusion is presented in section seven.

\section{Definition and Classification of Infrastructure}

The term 'infrastructure' is not a new concept and is increasingly becoming more widely used in various fields cutting across disciplines (e.g. economics, information technology) and sectors (government, military, academia and institutional investors). Finding a succinct definition and classification for infrastructure is important in enhancing the understanding of the dynamics of infrastructure as an asset class and the differences between types of infrastructure not only for investment purposes but also for policy making (Moteff et al, 2003). According to Baldwin and Dixon (2008) a definition of infrastructure must be consistent, across jurisdictions and over time, in order to be useful. However, Grimsey and Lewis (2002) consider that it is easier to recognise than to define.

According to Parker (2008) and RREEF (2008) infrastructure stocks have traditionally been divided into two broad categories: social and economic infrastructures. The social infrastructure comprises education, public healthcare and correctional facilities. These assets are often financed as public / private partnerships. Economic infrastructure consists of assets that support commerce and for which a fee is typically charged, examples include utilities, toll roads, airports, power stations and wind farms. Closely related to economic infrastructure is engineering infrastructure which according to ABS (2001) is a section of engineering construction that comprises all transportation systems including bridges, harbours, water storage and supply, sewerage and drainage, electrical generation, transmission and distribution, pipelines, recreation and telecommunications. Timotijevic (2008) further classified infrastructure into utility and non-utility infrastructures. Utility infrastructure such as electricity, water and gas provide essential services to communities but subject to strict regulation by government-related entities. As a result, utilities have a high level of regulatory risk (Figure 1). Indeed, there tend to be a correlation between regulation and risk, the less competitive assets such as the utilities are highly regulated and less risky while the more competitive assets are less regulated but incur higher risk factors.

Figure 1: Correlation between Regulation and Risk

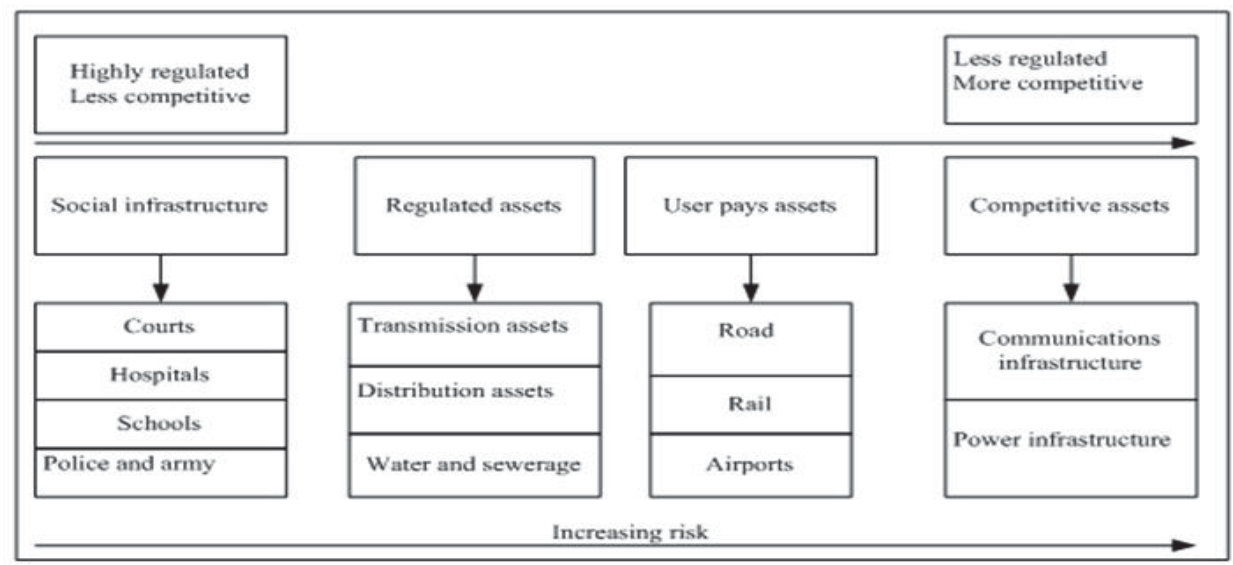

Source: Rickards (2008) 
However, a balance is sought by the regulatory bodies/entities between consumer satisfaction with respect to quality of service received and investors expected economic returns and stability. As a result of this perceived stability, these utility assets typically carry a higher level of gearing than the other infrastructure assets. Non-utility infrastructure assets include social infrastructure and economic infrastructures such as transportation infrastructures (toll roads, airports, ports and rail) and communication infrastructure and while there are controls on price increases, these assets can generate surplus returns through increased volume growth. As a result, they are leveraged to the economic cycle and feature patronage risk with respect to level of benefit to consumers (Timotijevic, 2008). Frischmann (2005) construes infrastructure as either traditional or non-traditional. Traditional infrastructures refer to physical resource systems made by humans for public consumption including but not limited to transportation systems, communication systems, governance systems and basic public services and facilities, such as schools, sewers, and water systems. In contrast, other resources that have the potential to significantly influence economic and social gains such as environmental resources, information resources, and internet resources are classified as non-traditional infrastructures.

\section{Significance and Economic Competitive Attraction of Infrastructure}

Extensive and efficient infrastructure is an essential driver of competitiveness (World Economic Forum, 2008). The entire life cycle of infrastructures, whether social or economic, existing or new, generally has significant effects on economic growth, from their creation, through their upgrading and maintenance and most outstandingly by their use (Sharma, 2006). As a result, infrastructure represents an important source of economic empowerment and revenue supplies to any government. Existing infrastructure affects current and future revenue requirements through the repayment of existing principal and interest on any financing that was used to acquire the infrastructure; costs associated with the use of the infrastructure such as power, labour and ancillary equipment; the related ongoing maintenance costs; and considerations for its future replacement (CICA and PSAB, 1999).

The significance of infrastructure quality and quantity is recognized across households, companies and governments. The services generated from infrastructure assets are usually consumed by both households and enterprises. Infrastructure is both a final consumption item and an intermediate consumption item that enhances welfare and increases output (Prud'homme, 2005). For instance, better transportation services that reduce travel costs and time, and more accessible water that reduce collection time, can allow households the opportunity to devote more time to income-earning activities (Fox, 1994). Beyond enhancing earning capacity and quality of life for low income groups, adequate infrastructure is a means of enhancing productivity and growth of firms; it is apparent that it plays a central role in generating external effects that fundamentally alter the capacity of the economy to produce goods and services (Rodríguez, 2006). Lakshmanan et al. (1985) conjecture that infrastructure provides basic services without which most primary, secondary or service activities can operate effectively.

At a more global scale, the economic importance of infrastructure has been the subject of extensive research since the late 1980s (Finkenzeller and Dechant, 2010). Impelled by the mounting pressure associated with increasing demand for infrastructure coupled with the growing significance of infrastructure, the World Economic Forum (2008) has been committed to an annual Global Competitiveness Report (GCR) reflecting on infrastructure and other pillars (Figure 2) of economic growth and competitiveness.

Figure 2: The 12 Pillars of Economic Competitiveness

\begin{tabular}{|c|c|}
\hline $\begin{array}{l}\text { Basic requirements } \\
\text { Institutions } \\
\text { - Infrastructure } \\
\text { - Macroeconomic stability } \\
\text { Health and primary education }\end{array}$ & $\begin{array}{l}\text { Key for } \\
\text { Factor-driven } \\
\text { Economies }\end{array}$ \\
\hline $\begin{array}{l}\text { Efficiency enhancers } \\
\text { - Higher education and training } \\
\text { - Loods market efficiency } \\
\text { - Financial market sophistication } \\
\text { - Technological readiness } \\
\text { - Market size }\end{array}$ & $\begin{array}{l}\text { Key for } \\
\text { Efficiency-driven } \\
\text { Economies }\end{array}$ \\
\hline $\begin{array}{l}\text { Innovation and sophistication } \\
\text { factors } \\
\text { - Business sophistication } \\
\text { - Innovation }\end{array}$ & $\begin{array}{l}\text { Key for } \\
\text { Innovation-driven } \\
\text { Economies }\end{array}$ \\
\hline
\end{tabular}

Source: The Global Competitiveness Report 2008-2009 @ 2008 World Economic Forum 
The report lists infrastructure as one of the key drivers of a country's economic attractiveness and competitiveness, next only to institutional framework. There is convincing evidence underpinning the significance of quality infrastructure in a country's economic positioning. For instance, Canada was promoted from 13th position because of its transport and telecommunications infrastructure, while France rose to 16th attracting credit for having the second best infrastructure in the world (Kennedy 2008). The question of sustainability becomes eminent as infrastructure will continue to play a vital role in economic and social development, not only because the infrastructure network of an economy is becoming increasingly important, but also because society is ever more dependent on the smooth running of a growing range of infrastructure services (OECD Policy Brief, 2008).

\section{Institutional Investment Characteristics}

Institutional investors have been defined by Davis (1996) as specialised financial institutions which manage savings collectively on behalf of small investors, towards a specific objective in terms of acceptable risk, return-maximisation and maturity of claims. A number of institutional investors including pension funds, mutual funds, hedge funds, sovereign wealth funds and private equity funds are involved in managing a vast collection of finance capital spread across a continuum of diverse asset classes, largely motivated by the inclination to enhance investment performance and reduce the volatility of portfolio performance. According to Daly (2008), institutional investors have a preference for higher yielding assets and investments which commonly display a low correlation with other asset classes and therefore can add appreciable diversification benefits within a mixed-asset portfolio.

Relating to portfolio theory, the three key determining factors for institutional investors' investment objectives are its expected return, risk, and correlation with other investments. Indeed, in modern finance theory, these are the only investment characteristics that matter (Nofsinger, 2008). In succinct terms, the underlying principle for the practical approach by institutional investors reflects on risk diversification and the harmonizing of asset and liability characteristics, thus by spreading risk across different asset classes, the total portfolio risk of the investment is reduced (Ashurst et al, 1998). Other vital characteristics of institutional investors consist of a form of risk pooling for small investors, consequently providing an improved trade-off of risk and return than is achievable by way of direct holdings. This involves, on the asset side, placing a premium on diversification, essentially by investing in a range of domestic securities which may include both debt and equity and also by international investment. There is also an inclination for liquidity, and hence a requirement for an efficiently large and liquid capital markets, trading standard or 'commoditised' instruments, thus offering the capable to adjust investment holdings in pursuit of objectives, in response to new information (Davis, 1996).

\section{Pension Funds}

Investment in infrastructure is increasingly gaining significance among institutional investors, particularly the pension funds, due to its attractive and resilient characteristics as a distinct diversifier of portfolio. According to Rakowski (2004) leading European pension funds and institutional investors were showing increasing interest in the infrastructure sector regardless of the inadequate knowledge of the broader infrastructure market and the practical problem of positioning infrastructure asset in a portfolio. However, pension funds are seeking alternatives to conventional asset classes that can yield returns commensurate with their long-term liabilities. Inderst (2009) highlights that in the past; pension fund commitment to infrastructure has been secured through listed companies such as utilities, or through real estate portfolios. However, some larger funds globally are beginning to invest via private-equity funds, or, occasionally, even directly. Major players in the infrastructure sector include Australian, Canadian and Dutch pension funds (Inderst, 2009), indeed Rakowski (2004) considered that in an established market like Australia, the investment focus of many pension funds, centred on infrastructure. It is not uncommon for Australian pension funds, in addition to investing in listed infrastructure stocks to allocate $5 \%$ of their portfolio to privately held infrastructure equity investments (Rakowski, 2004).

Investing in long lived assets such as infrastructure may offer higher or more stable returns and diversify portfolios, thereby ensuring that pension plans fulfil their obligations to pay benefits (Beeferman, 2008). They are usually established by government institutions, companies, or labour unions with much expectation from workers to get benefits at retirement. As a result, pension funds invest contributions in a wide range of assets (BankTrack, 2008). Carmichael and Palacios (2003) classify pension plans into public (unfunded) schemes, publicly-mandated contributory schemes and voluntary private retirement savings. Publicly-mandated pension contributions could be privately managed, or by government either directly, or indirectly through a specially-created management agency. Fully-funded pension schemes 
according to Reisen (1997) do not only provide benefits to the members but may exert influential externalities that positively affect the overall economy by raising the supply of long-term funds, strengthening the effectiveness of fund allocation and stimulating the financial system of a country.

Pension funds are major players in the financial markets (BankTrack, 2008) and complement the role of government because of their high investment capacity (Josa-Fombellidaa and Rincón-Zapaterob, 2009). The enormous pool of resources created by pension funds gives them the edge as a force to be reckoned with in the global infrastructure markets.

The pension assets for United Kingdom was about 80\% and highest for the year 2000 followed by the United States. The United Nations Environment Programme Finance Initiative (UNEP FI) Asset Management Working Group and The United Kingdom Social Investment Forum (UKSIF) Sustainable Pensions Project (2007) in recognition of the leading role of pension funds in the UK, assists and encourages UK pension funds to adopt more sustainable and responsible investment strategies, so as to protect and enhance long-term shareholder value and financial returns for beneficiaries.

When both OECD and non-OECD economies are taken together, the world pension funds were equivalent to USD 16.9 trillion in 2006, up from USD 14.2 trillion in 2004, while the associated growth rate was $9.0 \%$ during this two-year period (OECD, 2007). Pension fund involvement in infrastructure has shown a remarkable growth pattern and is expected to grow rapidly over the long term (Figure 3). According to Tal (2009) global infrastructure investment has seen an increase from pension funds' assets allocation up from only $2 \%$ previously to $5 \%$, and this allocation is expected to keep growing, with pension funds allocating between $10 \%$ and $15 \%$ of their assets to infrastructure investment by 2017injecting over \$200bn of new funds to the infrastructure sector (Tal, 2009).

Figure 3: Pension Fund Investment in Infrastructure Expected to Grow Rapidly

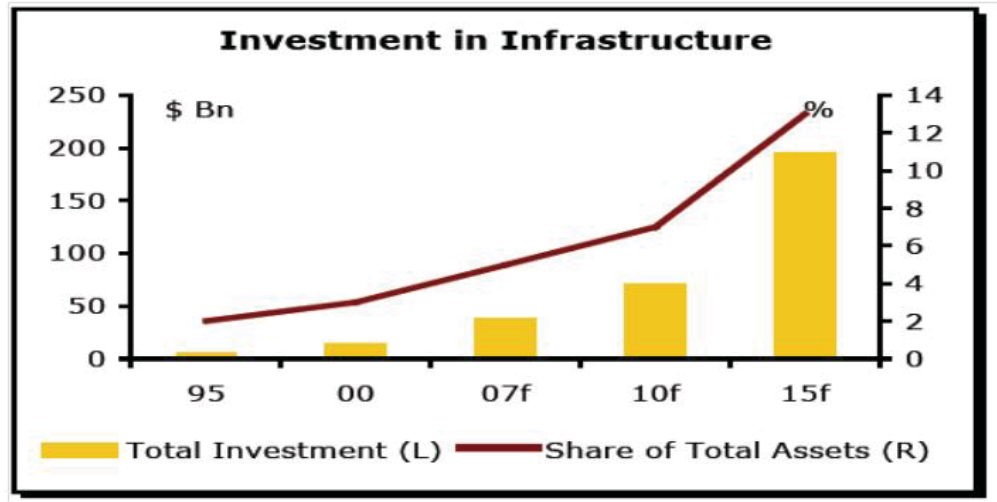

Source: Statistics Canada, CIBCWM Adapted from Tal B. (2009)

Every form of investment poses one form of risk or the other; however, pension funds pose a different set of risks compared to other financial institutions. Srinivas et al (2000) identify three risks associated with pension funds (Table 1) namely:

- Systematic (undiversifiable) market risk: current generations cannot trade with unborn ones, so efficient intergenerational risk sharing cannot take place;

- Systemic risk: Asymmetric information problems in banking systems can lead to bank runs, and make financial systems fragile;

- Agency risks: in financial markets, trading often takes place between parties with different information, creating problems of moral hazard and adverse selection. 
Table 1: A Classification of Investment Risks In Pension Funds

\begin{tabular}{|c|c|c|c|c|}
\hline Type of risk & Example & Risk reduction & Example & New risk created \\
\hline $\begin{array}{l}\text { Non-systematic } \\
\text { market risk }\end{array}$ & $\begin{array}{l}\text { Management } \\
\text { inefficiency or } \\
\text { inexperience (fund } \\
\text { or industry specific) }\end{array}$ & $\begin{array}{l}\text { Portfolio } \\
\text { diversification }\end{array}$ & $\begin{array}{l}\text { Diversification } \\
\text { across countries or } \\
\text { intermediaries }\end{array}$ & \\
\hline \multirow[t]{2}{*}{$\begin{array}{l}\text { Systematic market } \\
\text { risk }\end{array}$} & \multirow[t]{2}{*}{$\begin{array}{l}\text { Global asset price } \\
\text { volatility }\end{array}$} & $\begin{array}{l}\text { Government } \\
\text { provides risk- } \\
\text { reducing } \\
\text { instruments }\end{array}$ & $\begin{array}{l}\text { Inflation-indexed } \\
\text { bonds }\end{array}$ & Policy risk \\
\hline & & $\begin{array}{l}\text { Government } \\
\text { guarantee }\end{array}$ & $\begin{array}{l}\text { Minimum pension } \\
\text { or real rate of return } \\
\text { guarantee }\end{array}$ & $\begin{array}{l}\text { Agency risk/moral } \\
\text { hazard } \\
\text { Policy risk }\end{array}$ \\
\hline \multirow[t]{2}{*}{ Systemic risk } & \multirow[t]{2}{*}{ Banking crisis } & $\begin{array}{l}\text { Prudential } \\
\text { regulation }\end{array}$ & Capital adequacy & Policy risk \\
\hline & & $\begin{array}{l}\text { Government } \\
\text { guarantee }\end{array}$ & Deposit insurance & $\begin{array}{l}\text { Agency risk/moral } \\
\text { hazard } \\
\text { Policy risk }\end{array}$ \\
\hline \multirow[t]{2}{*}{ Agency risk } & \multirow{2}{*}{$\begin{array}{l}\text { Moral hazard: } \\
\text { fraud, pension mis- } \\
\text { selling, excessively } \\
\text { risky investments } \\
\text { Adverse selection: } \\
\text { reasonably priced } \\
\text { insurance not } \\
\text { universally available }\end{array}$} & $\begin{array}{l}\text { Prudential } \\
\text { regulation }\end{array}$ & $\begin{array}{l}\text { Diversification, } \\
\text { limits on self- } \\
\text { investment }\end{array}$ & Policy risk \\
\hline & & $\begin{array}{l}\text { Government } \\
\text { guarantee }\end{array}$ & Compensation & $\begin{array}{l}\text { Agency risk/moral } \\
\text { hazard }\end{array}$ \\
\hline
\end{tabular}

Source: Srinivas et al (2000)

Regardless of the risk associated with pension funds, there are growing instances of pension fund investment in infrastructure; for example, \$14.6bn retirement system of Illinois State Universities has dedicated a maiden $1 \%$ allocation to infrastructure investment. Similarly Wyoming Retirement System committed $\$ 120$ million, equating to nearly 2\% of its total assets to infrastructure funds in 2008 (Preqin Infrastructure Review, 2008). The California Public Employees Retirement System (CalPERS) readjusted its investment policy guidelines to accommodate up to $3.0 \%$ of its total assets in infrastructure compared to its previous level of $0.2 \%$ (Froehlich, 2008). A further indication of pension funds' optimism for infrastructure investment is established by a recent $\$ 1 \mathrm{bn}$ (€644.m) of capital in infrastructure investments by the California State Teachers Retirement System (Peterson, 2009).

According to an annual survey (Watson Wyatt, 2008), alternative assets managed on behalf of pension funds by the world's largest 99 investment managers grew by $40 \%$ in 2007 to US\$822bn from US\$586bn in 2006 and included infrastructure for the first time in the 2008 survey, which accounted for $5 \%$ of the assets.

The survey reveals a concentration of investments in the European region, portraying the attractiveness of the region to pension funds with the largest portion (53\%) of investments. This is also reflected in the allocation of $54 \%$ of pension fund assets to infrastructure within the Europe region (Table 2). Asia-Pacific and North America account for 22\% and $21 \%$ of pension fund infrastructure investors' investment concentration respectively, while the allocation of pension fund alternative assets to these regions account for $21 \%$ each.

However, a more recent survey by Watson Wyatt (2009) in conjunction with the Financial Times revealed that the true effect of the global financial crisis on asset value was $1 \%$ in 2008 compared to US\$817bn in 2007, a separate survey by Watson Wyatt (2009) shows that the US, Japan and the UK remained the largest pension markets in the world. Inderst (2009) reported that superannuation funds in Australia allocates about $5 \%$ of their assets to infrastructure with some funds allocating up to $10 \%$, characterising them as pillars behind private capital flow into infrastructure. In the US, the \$173bn California Public Employees Retirement System (CalPERS) adopted a new investment policy in 2008 with a target 3 per cent allocation, or $\$ 7.2 \mathrm{bn}$, in infrastructure ${ }^{1}$.

Table 2: Allocation of Pension Fund to Alternative Assets

\begin{tabular}{|l|c|c|c|c|}
\hline \multicolumn{1}{|c|}{ Alternative Assets } & Europe \% & North America \% & Asia Pacific \% & Other \% \\
\hline Real Estate & 39 & 47 & 10 & 3 \\
\hline Private Equity FoF & 40 & 53 & 5 & 3 \\
\hline Fund of Hedge Funds & 35 & 49 & 13 & 3 \\
\hline Infrastructure & 54 & 21 & 21 & 4 \\
\hline Commodities & 32 & 21 & 1 & 46 \\
\hline Total & 36 & 47 & 10 & 3 \\
\hline
\end{tabular}

Source: Watson Wyatt (2008) 
Inderst (2009) comments that the majority of pension fund investments are through infrastructure funds, however some bigger Canadian and Dutch pension funds have started to invest directly. These pension funds are often co-investors with specialist funds, and hope to build up the internal expertise in-house over time. Pension funds have the potential to accumulate a significant amount of resources. In 2004, the Macquarie European Infrastructure Fund, recognized as the first pan-European dedicated infrastructure fund raised E427m from various sources such as Stichting Pensioenfonds, ABP of the Netherlands, Oslo Pensjonsforsikring and Norway's largest municipal pension plan, Generali, Italy's largest insurer, and Dexia Credit Local, a subsidiary of the Franco-Belgian banking group Dexia (Rakowski, 2004). In 2006, pension funds in OECD countries saw a sustained growth with total assets increasing to $\$ 16.2$ trillion from $\$ 15.0$ trillion in 2005 , however, in US dollar terms, the growth rate for 2005-2006 was $8.2 \%$, which was less than the $9.8 \%$ growth for the previous year (OECD, 2007).

Similarly, pension funds in non-OECD economies have also seen a build up of assets, though the sector is relatively smaller than the OECD regions, with a total of USD 0.6 trillion. Conversely, pension assets in non-OECD economies grew much faster than those in OECD countries, while the average growth rate between 2004 and 2006 in G10 countries and in the Euro area was $8.1 \%$ and $13.6 \%$ respectively, this ratio was much higher in the Latin American countries (26.9\%) and BRICs (23.3\%). The aggregate pension fund market has a size of US\$24.6tr worldwide (OECD, 2007), by extrapolation, an allocation of $3 \%$ of pension fund assets would make approximately US $\$ 500 \mathrm{bn}$ available for infrastructure investments (Inderst, 2009).

However, a major determinant of success is the role played by the government in the growth of infrastructure investment. Governments could advance development of infrastructure through an appropriate regulatory framework that could encourage private sector involvement by creating a viable innovative vehicle of infrastructure financing such as the pension funds. The size of a pension fund's ownership stake in any particular investment will have a significant influence on the scale of investment options available to pension funds (Beeferman, 2008). Tapia (2008) highlights two alternative approaches to mitigating portfolio regulation for privately managed pension funds; the prudent person principle and quantitative portfolio restrictions. While the prudent person approach restricts the obligation of rigid portfolio limits and focuses on regulating the activities of investment managers, the quantitative principle recommends a range of investment restrictions which investment managers are obliged to follow in their portfolio allocation on behalf of pension funds.

\section{Sovereign Wealth Funds (SWFs)}

According to Truman (2007) sovereign wealth funds are the latest topic de jour in international finance markets. They are characterized by intrinsic worth-ownership control by the government and pursuit of high risk-adjusted returns as the fundamental objective (Park, 2008). However, there is no generally accepted definition of the term. According to Gabriel (2008) the term itself is far newer, and had never been mentioned in the mainstream national British media prior to 16 June 2007, by 1 November 2008, the total number of mentions had reached 1,250. In the opinion of Truman (2008) the broadest definition of a sovereign wealth fund (SWF) is a collection of government-owned or government-controlled assets. They are therefore government investment vehicles that acquire international financial assets to earn a higherthan-risk-free rate of return (Drezner, 2008). SWFs are generally funded by the transfer of foreign exchange assets that are invested with a long term objective mostly in a foreign country. Key factors responsible for the rapid growth of foreign assets and their influence on the international capital markets particularly by oil rich countries include high oil prices, financial globalization, and the persistent global imbalances. As a result, the number and size of SWFs are rising fast and their presence in international capital markets is becoming more prominent (International Monetary Fund, 2008).

More constricted definitions may exclude government financial or non-financial corporations, purely domestic assets, foreign exchange reserves, assets owned or controlled by sub-national governmental units, or some or all government pension funds (Truman, 2008). The influence of sovereign wealth funds on economic growth and expansion can not be over-emphasised. For instant, some governments have fashioned wholly-owned funds to support their development objectives, such as constructing infrastructure; examples include Temasek Holdings of Singapore, Khazanah Nasional Berhad of Malaysia and the National Development Fund of Venezuela (The Corner House, 2008).

The Corner House (2008) maintain that it was in the early 1950s after the Second World War that the first wave of more recently established SWFs started. However, approximately 62\% of SWFs have been established since 2000 (Figure 4) prior to which the rate of new funds being established was much slower. Beside the growth in their number and size, sovereign wealth funds have also sought to diversify their investments across asset classes and geographies characterised by motivation for higher returns. This, coupled with the increase in aggregate assets under management, has fuelled the expectation in the rate of global investments made by SWFs (Preqin, 2009 SWF). 
Figure 4: Breakdowns of SWFs by Date of Establishment

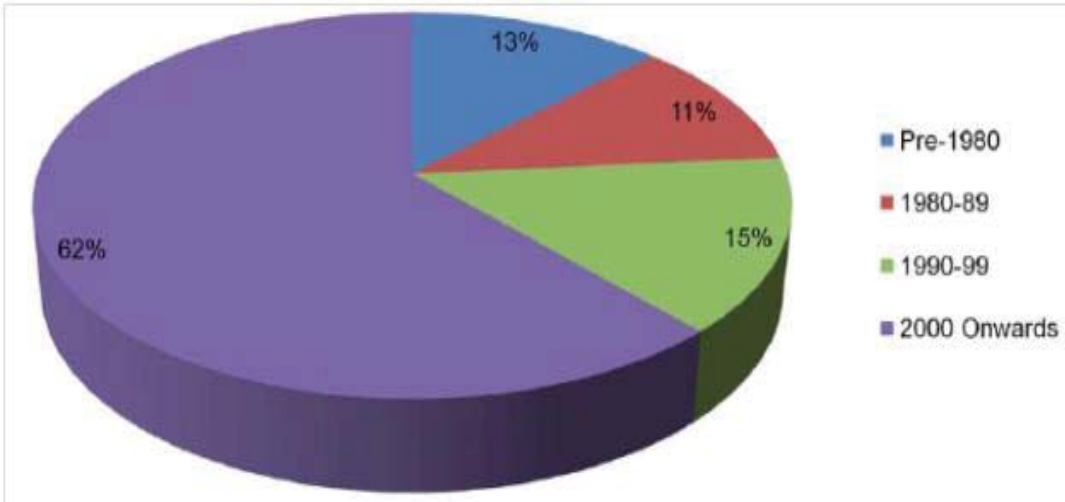

Source: Preqin (2009 SWF)

Surprisingly, relatively little is known about most SWFs, and this is coupled with the divergence of views of most market estimates of their size and magnitude. According to the US Department of the Treasury (2007) market estimates of cumulative assets of recognized SWFs range from $\$ 1.5-2.5$ trillion and are comparatively concentrated. Some estimate that four funds alone (Abu Dhabi Investment Authority (ADIA), Government of Singapore Investment Corporation (GIC), Government Pension Fund - Global (GPFG) and various funds of Saudi Arabia) account for around two-thirds of total SWF assets. There are only two funds from the Westminster style of government that feature in the list of SWF (Table 3). Australian Government Future Fund (AGFF) US $\$ 50 \mathrm{bn}$ and Alberta Heritage Fund (AHF) of Canada US\$17bn (Sanyal, 2008). Unexpectedly, the Alaska Permanent Reserve Fund Corporation (APRF) of the United States is not among the first twelve of leading global SWFs. 
Table 3: A Worldwide Overview of Sovereign Wealth Funds

\begin{tabular}{|c|c|c|c|c|}
\hline Country & Fund & $\begin{array}{l}\text { AuM } \\
\text { (USD bn) }\end{array}$ & $\begin{array}{l}\text { Inception } \\
\text { year }\end{array}$ & Source \\
\hline United Arab Emirates & Abu Dhabi Investment Authority (ADIA) & 875 & 1976 & Oil \\
\hline Singapore & Government of Singapore Investment Corporation (GIC) & 330 & 1981 & Non-commodity \\
\hline Norway & Government Pension Fund - Global (GPFG) & 322 & 1990 & Oil \\
\hline Saudi Arabia & Various funds & 300 & NA & Oil \\
\hline Kuwait & Kuwait Investment Authority (KIA) & 250 & 1953 & Oil \\
\hline China & China Investment Company Ltd. & 200 & 2007 & Non-commodity \\
\hline Hong Kong & Hong Kong Monetary Authority Investment Portfolio & 140 & 1998 & Non-commodity \\
\hline Russia & Stabilization Fund of the Russian Federation (SFRF) & 127 & 2003 & Oil \\
\hline China & Central Hujin Investment Corp. & 100 & 2003 & Non-commodity \\
\hline Singapore & Temasek Holdings & 108 & 1974 & Non-commodity \\
\hline Australia & Australian Government Future Fund (AGFF) & 50 & 2004 & Non-commodity \\
\hline Libya & Reserve Fund & 50 & NA & Oil \\
\hline Qatar & Qatar Investment Authority (QIA) & 40 & 2000 & Oil \\
\hline United States & Alaska Permanent Reserve Fund Corperation (APRF) & 40 & 1976 & Oil \\
\hline Brunei & Brunei Investment Agency (BIA) & 35 & 1983 & Oil \\
\hline Ireland & National Pensions Reserve Fund (NPRF) & 29 & 2001 & Non-commodity \\
\hline Algeria & Reserve Fund & 25 & NA & Oil \\
\hline South Korea & Korea Investment Corporation (KIC) & 20 & 2006 & Non-commodity \\
\hline Malaysia & Khazanah Nasional BHD (KNB) & 18 & 1993 & Non-commodity \\
\hline Kazakhstan & Kazakhstan National Fund (KNF) & 18 & 2000 & Oil, gas, metals \\
\hline Canada & Alberta Heritage Fund (AHF) & 17 & 1976 & Oil \\
\hline Taiwan & Taiwan National Stabilisation Fund (TNSF) & 15 & 2000 & Non-commodity \\
\hline United States & New Mexico State Investment Office Trust Funds & 15 & 1958 & Non-commodity \\
\hline Iran & Foreign Exchange Reserve Fund & 15 & 1999 & Oil \\
\hline Nigeria & Excess Crude Account & 11 & 2004 & Oil \\
\hline New Zealand & New Zealand Superannuation Fund & 10 & 2003 & Non-commodity \\
\hline Oman & State General Stabilisation Fund (SGSF) & 8.2 & 1980 & Oil, gas \\
\hline Chile & Economic and Social Stabilization Fund (ESSF) & 6.0 & 2007 & Copper \\
\hline Botswana & Pula Fund & 4.7 & 1993 & Diamonds et al. \\
\hline United States & Permanent Wyoming Mineral Trust Fund (PWMTF) & 3.2 & 1974 & Minerals \\
\hline Norway & Government Petroleum Insurance Fund (GPIF) & 2.6 & 1986 & Oil \\
\hline Azerbajjan & State Oil Fund & 1.5 & 1999 & Oil \\
\hline East Timor & Timor-Leste Petroleum Fund & 1.2 & 2005 & Oil, gas \\
\hline Venezuela & Investment Fund for Macroeconomic Stabilization (FIEM) & 0.8 & 1998 & Oil \\
\hline Kiribati & Revenue Equalisation Reserve Fund (RERF) & 0.6 & 1956 & Phosphates \\
\hline Chile & Chile Pension Reserves Fund & 0.6 & 2007 & Copper \\
\hline Uganda & Poverty Action Fund & 0.4 & 1998 & Aid \\
\hline Papua New Guinea & Mineral Resources Stabilization Fund (MRSF) & 0.2 & 1974 & Minerals \\
\hline Mauritania & National Fund for Hydrocarbon Reserves & 0.0 & 2006 & Oil, gas \\
\hline United Arab Emirates & Dubai Intem. Financial Centre Investments (DIFC) & NA & 2002 & Oil \\
\hline Angola & Reserve Fund for Oil & NA & 2007 & Oil \\
\hline Total & & $3,190.00$ & & \\
\hline \multicolumn{5}{|c|}{ Memorandum items: Planned SWF projects } \\
\hline China & State Foreign Exchange Investment Corporation (SFEIC) & 200 & $2007 \theta$ & Non-commodity \\
\hline Russia & Future Generations Fund of the Russian Federation (SFRF) & 32 & $2008 e$ & Oil \\
\hline Bolivia & (Establishment of SWF planned) & NA & $2008 \mathrm{e}$ & Oil \\
\hline Japan & (Establishment of SWF presumed) & NA & NA & Non-commodity \\
\hline \multicolumn{2}{|c|}{ Total ind. Memorandum items } & $3,422.00$ & & \\
\hline
\end{tabular}

Sources: Deutsche Bank Research (2007)

The investment potential of countries can be partly assessed by the level of available funds for infrastructure provision. SWF funds therefore reveal the availability of surplus government revenues and reserves in the relevant countries and the apparent need to manage funds with a view to meeting definite future liquidity needs according to the fund's established purpose and levelling income streams (Deutsche Bank Research, 2007). In addition, market estimates currently attribute approximately two-thirds of SWFs assets to commodity funds and the remaining one-third to noncommodity funds (US Department of the Treasury, 2007).

SWFs constitute a crucial source of finance, considering their established funding sources; they are underpinned by certain key characteristics which tend to work in their favour. Compared to other institutional investors such as pension funds; various sovereign wealth funds do not have future liabilities that they are constrained to pay out on, and do not 
have external investors able to withdraw capital at short notice. As a result they have long-term investment horizons and often are relatively free to invest in various asset classes (Figure 5) including the risky alternative investment types such as hedge funds, private equity and infrastructure (Preqin, 2009 SWF).

Figure 5: Proportions of SWFs Investing in Different Asset Classes

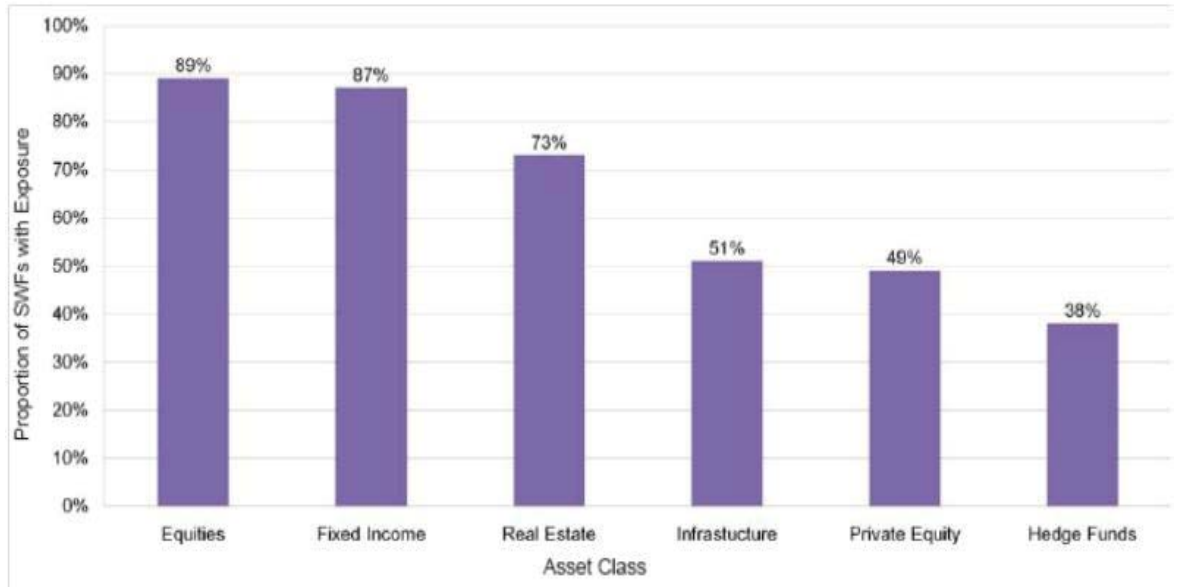

Source: Preqin (2009 SWF)

Viewed differently from several quarters, sovereign wealth funds tend to be criticized on a numerous bases. The Deutsche Bank Research (2008) although recognising the weight of influence sovereign wealth funds on the global financial markets, identifies areas of concern such as fear of industrial espionage or geopolitical threats. Yi-chong (2009) express concern on the size and speed of growth of SWFs, estimated to reach $\$ 12$ trillion by 2015 up from $\$ 500$ million in 1990. The current size of SWFs is US\$3.1 trillion (Table 4).

Table 4: Global Assets under Management (US\$ trillion)

\begin{tabular}{|l|c|}
\hline \multicolumn{1}{|c|}{ Pension funds } & 21 \\
\hline Mutual funds & 19.6 \\
\hline Insurance companies & 18.5 \\
\hline Reserves ex gold & 4.2 \\
\hline SWFs & 3.1 \\
\hline Hedge funds & 1.4 \\
\hline Private equity & 0.8 \\
\hline Total & 68.6 \\
\hline
\end{tabular}

Source: Yi-chong (2009)

Park (2008) pinpoints two areas of concern relating to their collective size and their wide-ranging lack of transparency, aggravating concerns about the possible risks they are capable of creating for global financial stability. However, not all SWFs are opaque: according to The Corner House (2008) some sovereign wealth funds are very transparent and widely disclose their asset size, investment portfolio and returns. For instance, Norway's Government Pension Fund-Global (GPF) and Canada's Alberta Heritage Fund demonstrate high levels of transparency such that the GPF ranks first in the Linaberg-Maduell Transparency Index of the Sovereign Wealth Fund Institute.

Sovereign wealth funds tend to be classified based on certain factors such as the source of the foreign exchange assets and purpose of establishment or objectives. Classifying SWFs based on source of the foreign exchange assets, the US Department of the Treasury (2007) identify two main forms: commodity funds, established through commodity exports (either owned or taxed by the government) and non-commodity funds, typically established through transfers of 
assets from official foreign exchange reserves. SWFs are a heterogeneous group and may serve various purposes. The International Monetary Fund (2008) distinguish five types of SWFs based on their purpose of establishment: (i) stabilization funds, where the primary objective is to insulate the budget and the economy against commodity (usually oil) price swings; (ii) savings funds for future generations, which aim to convert non-renewable assets into a more diversified portfolio of assets; (iii) reserve investment corporations, whose assets are often still counted as reserve assets, and are established to increase the return on reserves; (iv) development funds, which typically help fund socio-economic projects or promote industrial policies that might raise a country's potential output growth; and (v) contingent pension reserve funds, which provide (from sources other than individual pension contributions) for conditionally unspecified pension liabilities on the government's balance sheet (International Monetary Fund, 2008).

\section{Conclusion and Recommendation}

The paper examined the emergence of key institutional players within the infrastructure investment landscape particularly pension funds and sovereign wealth funds. The increasing influence of institutional investors has inspired a revolutionary development in financial systems and are now been seen as sources of long-term capital with a sphere of investment linked to the often long-term nature of their liabilities. Institutional investors also ease the dependence on the banking institutions, thus providing a cushion effect during period of adverse financial conditions. Also, institutional investors particularly pension funds and sovereign funds have the capacity to pool enormous resources into the infrastructure market, thus emphatically projecting them as a force to be reckoned with in the global infrastructure markets.

Although institutional investors' interest in infrastructure is driven by its attractive and resilient characteristics as a distinct diversifier of portfolio, this paper recommends a broader understanding of the mechanisms and operations of the infrastructure market and a deeper knowledge of the practical problem of positioning infrastructure asset in a portfolio particularly by the institutional investors.

The findings from this paper as relating to the current institutional and upcoming players such as hedge funds and private equity in financing infrastructure assets has informed a growing concern that borders on policy structures particularly with reference to issues of regulations and transparency. The paper highlights the significance of satisfactory policy within the individual institutional investors' profile and further recommends a more acceptable and adequate regulatory platform from the public sector perspective. This will appreciably underpin the global agenda of bridging the large-scale infrastructure financing gap.

\section{References}

ABS, (2001) Government Financial Statistics, Australia www.abs.gov.au Accessed October, 2009

BankTrack, (2008) What is... Pension Fund Center for Research on Multinational Corporations http://www.banktrack.org/download Iwhat_is_a_pension_fund_/what_is_a_pension_fund.pdf Accessed July, 2009

Beeferman, L.W. (2008) Pension Fund Investment in Infrastructure: Pensions and Capital Stewardship Project Labor and Worklife Program Harvard Law School; Occasional Paper Series - No.3 December

Carmichael, J. and Palacios, R. (2003) A Framework for Public Pension Fund Management: Paper presented to $2^{\text {nd }}$ Public Pension Fund Management Conference, World Bank, Washington DC, May 5-7

CICA and PSAB, (1999) Accounting for Infrastructure in the Public Sector; The Canadian Institute of Chartered Accountants' (CICA) Research Studies department in conjunction with the Public Sector Accounting Board (PSAB), http://www.cica.ca/multimedia /Download Library/Standards/PSAB/English/e fmi100.pdf Accessed July, 2009

Davis, K.T. (2008) Listed Infrastructure Funds: Funding and Financial Management http://papers.ssrn.com/sol3/papers.cfm ?abstract_id=1337473 Accessed March, 2009

Deutsche Bank, (2007) Infrastructure Investment Introductory Notes http://www.uksip.org/assets/166/Agostino_D.pdf Accessed July, 2009

Deutsche Bank, (2008) Global Markets- 2008 Alternative Investment Survey Deutsche Bank's Hedge Fund Capital Group http://www.db.com/medien/en/downloads/2008_Alternative_Investment_Survey.pdf Accessed March, 2009

Drezner, D.W. (2008) Sovereign Wealth Funds and the (In) Security of Global Finance Journal of International Affairs 62 (1), pp. 115-130

EnnisKnupp, (2008) Global Infrastructure Presentation for State University Retirement System for Illinois http://www.surs.com/pdfs Iminutes/x_inv/ex09_08.pdf Accessed March, 2009

Finkenzeller, K., Dechant, $\bar{T}$. and Schafers, W. (2010) Infrastructure: A New Dimension of Real Estate? An Asset Allocation Analysis Journal of Property Investment \& Finance, 28 (4), pp. 263-274

Fox, W. F. (1994) Strategic Options for Urban Infrastructure Management Urban Management Programme World Bank, Washington DC Frischmann, B. M. (2005) An Economic Theory of Infrastructure and Commons Management Minnesota Law Review, 89, pp. 917-1030

Froehlich, R. J. (2008) Infrastructure as an Asset Class DWS Investment 
Grimsey, D and Lewis M.K (2002) Evaluating the Risks of Public Private Partnerships for Infrastructure Projects International Journal of Project Management, 20 (2), pp. 107-118

Inderst, G. (2009) Pension Fund Investment in Infrastructure OECD Working Papers on Insurance and Private Pensions, No. 32 http://www.oecd.org/dataoecd/41/9/42052208.pdf Accessed October, 2009

Josa-Fombellidaa, R. and Rincón-Zapaterob, J.P. (2009) Optimal Asset Allocation for Aggregated Defined Benefit Pension Funds With Stochastic Interest Rates European Journal of Operational Research Elsevier, 201 (1), pp. 211-221

Kim, K-H. (1997) Housing Finance and Urban Infrastructure Finance Urban Studies, 34 (10), pp. 1597- 1620

Lakshmanan, T. R. and Elhance, A. (1985) Impact of Infrastructure on Economic Development In Snickers F., Johansson B. and Lakshmanan T. R. (Eds.) Economic Faces of the Building Sector, Stockholm Council of Building Research, Umea

Merna, T. and Njiru, C. (2002) Financing Infrastructure Projects; Construction Management Series, Thomas Telford, London

Moteff, J., Copeland, C. and Fischer, J. (2003) Critical Infrastructures: What Makes an Infrastructure Critical? The Library of Congress http://www.fas.org/irp/crs/RL31556.pdf Accessed January, 2009

OECD, (2007) Pension Markets in Focus, No. 4, November

OECD (2008) Organisation for Economic Co-operation and Development- Infrastructure to 2030 policy brief January 2008

Park, D. (2008) Developing Asia's New Sovereign Wealth Funds and Global Financial Stability; ADB Briefs October No. 1 http://www.adb.org/Documents/Briefs/ADB-Briefs-001-Sovereign-Wealth-Funds.pdf Accessed July, 2009

Parker, G. (2008) Investing in Asian Infrastructure: The S\&P Asia Infrastructure Index July http://www2.standardandpoors.com /spf/pdf/index/Investing Asian Infrastructure 0708.pdf Accessed March, 2009

Peng, H.W. and Newell, G. (2007) The Significance of Infrastructure in Australian Investment Portfolios Pacific Rim Property Research Journal, Vol. 13 No 4 pp 423- 450

Peterson, J. (2009) CalSTRS Focuses Eye on Infrastructure 12 June IPE International Publishers Limited http://ipe.co/realestate larticleprint.php?id=28243 Accessed September, 2009

Preqin Infrastructure Review, (2008) Pension Funds Turning to Infrastructure Preqin Infrastructure Spotlight, September 1 (1)

Prud'homme, R. (2005) Infrastructure and Development In Francois B. \& Boris Pleskovic B. (Ed.) Lessons of Experience Washington, The World Bank and Oxford University Press, pp. 153-181

Reisen, H. (1997) Liberalizing Foreign Investments by Pension Funds: Positive and Normative Aspects World Development, 25 (7), pp. 1173-I 182

Rodríguez, F. (2006) Have Collapses in Infrastructure Spending led to Cross-Country Divergence in per Capita GDP? Paper prepared as a background note for the 2006 World Economic and Social Survey of the United Nations Department of Economic and Social Affairs http://www.un.org/esa/policy/backgroundpapers/rodriguez_1.pdf Accessed July, 2009

RREEF (2008) China infrastructure investment RREEF Research London

Sanyal, K. (2008) Foreign Investment Rules and Sovereign Wealth Funds Economics Section Parliament of Australia Parliamentary Library June 24

Sharma, M. (2006) Innovative Infrastructure Financing Strategy in India; Journal of International Research Publications, Economy \& Business 1, pp.55-71

Srinivas, P.S., Whitehouse, E. and Yermo, J. (2000) Regulating Private Pension Funds' Structure, Performance and Investments: Crosscountry Evidence Social Protection Discussion Paper Series http://www.pension.kiev.ua/files/0113.pdf Accessed July, 2009

Tal, B. (2009) Capitalizing on the Upcoming Infrastructure Stimulus CIBC World Markets Inc. Occasional Report No. 66, January 26

Tapia, W. (2008) Comparing Aggregate Investment Returns in Privately Managed Pension Funds: An Initial Assessment OECD Working Papers on Insurance and Private Pensions No. 21 http://www.oecd.org/dataoecd/39/5/41408063.pdf Accessed July, 2009

The Corner House, (2008) Sovereign Wealth Funds: Some Frequently Asked Questions Corner House Briefing http://www.thecornerhouse.org.uk/pdf/briefing/38SWFFAQs.pdf Accessed July, 2009

Timotijevic, D. (2008) Infrastructure on the Defensive: The Performance of Infrastructure in a Credit Crisis

http://www.mercer.com/summary.htm?siteLanguage=100\&idContent=1326325 Accessed June, 2009

Truman, E. (2007) Sovereign Wealth Funds: The Need for Greater Transparency and Accountability Peterson Institute for International Economics http://www.iie.com/publications/pb/pb07-6.pdf Accessed June, 2009

UKSIF, (2008) Sustainable Alternatives- Sustainable Investment Opportunities for Pension Funds in Alternative Asset Classes UKSIF Sustainable Pensions Project http://www.uksif.org/cmsfiles/281411/SustainableAlternatives.pdf Accessed June, 2009

Watson Wyatt, (2008) Global Alternatives Survey Including the Global Alternatives 99 http://www.watsonwyatt.com/research /pdfs/GAS08.pdf Accessed July, 2009

Williams, M. (2009) Infrastructure Investment Opportunities Cliffwater http://www.cliffwater.com/research/Cliffwater\%200verview \%20of\%20Infrastructure\%20Investing\%20-\%20Jan\%2027\%202009.pdf Accessed August, 2009

World Economic Forum, (2009) Globalization of Alternative Investments Working Papers Vol. 2, The Global Economic Impact of Private Equity Report 2009 